Tér és Társadalom 17. évf. 2003/1. 131-153. p.

Tér és Társadalom

XVII. évf. 2003

1: $131-183$

KITEKINTÖ

\title{
AZ EURÓPAI SZOCIÁLIS ALAP ÉS AZ EURÓPAI UNIÓ OKTATÁSPOLITIKÁJA
}

\section{(The European Social Fund and the Educational Policy of the European Union)}

FORGÁCS ANDRÁS

Kulcsszavak:

Európai Unió Európai Szociális Alap Foglalkoztatáspolitikai Irányelvek Nemzeti Fejlesztési Terv oktatáspolitika humáneröforrás-fejlesztés egész életen át tartó tanulás

Az elmúlt néhány év során az Európai Unió felfogásában az oktatáspolitika úm. felértékelödött, a közösségi dokumentumokban az oktatást és a képzést olyan stratégiai ágazatnak tekintik, amely a humánerôforrás-fejlesztés pilléreként az Unió, illetve a tagállamok versenyképességének, kiegyensúlyozott târsadalmi, gazdasági fejlödésének nem csupán elöfeltétele, hanem generálója is. A tanulmány elsödleges célja annak bemutatása, hogy az Európai Szociális Alap milyen formában támogatja, ill. támogathatja az oktatási, képzési rendszerek fejlesztését, korszerüsitését. A szerzó ezzel összefuggésben vizsgálja azt is, hogy az uniós csatlakozás nyomán Magyarország számára milyen pótlólagos potenciális fejlesztési források nyílhatnak meg az oktatás, képzés terilletein, valamint, hogy a Nemzeti Fejlesztési Terv e tekintetben milyen konkrét elgondolásokat tartalmaz.

\section{Bevezetés}

Az oktatáspolitika európai uniós felfogásában figyelemre méltó és minőségileg újszerü fejlemény, hogy az elmúlt 5-6 esztendőben született átfogó politikai, valamint specifikusan az oktatási, szakképzési kérdéseknek szentelt közösségi dokumentumok, az oktatást és a képzést kivétel nélkül olyan stratégiai ágazatnak tekintik, amely a humánerőforrás-fejlesztés pilléreként a Közösség és a tagállamok versenyképességének, kiegyensúlyozott társadalmi, gazdasági fejlődésének nem csupán elöfeltétele, hanem motorja is. Ezzel összhangban, az oktatás, képzés helyzetét, feladatait, fejlesztési céljait mindenkor a gazdasági növekedés, a foglalkoztatáspolitika és a szociálpolitika átfogó összefüggéseibe ágyazottan vizsgálják, ill. határozzák meg.

Egyértelmúen kimutatható, hogy a Közösség vezetỏ politikusai, csakúgy mint az Európai Bizottság és a tagállamok oktatási-képzési politikáját irányító felelỏs tényezők - természetesen nem függetlenül az OECD, az UNESCO, a Világbank és más nemzetközi szervezetek, tudományos múhelyek égisze alatt az oktatás és képzés gazdasági, társadalmi összefüggéseivel foglalkozó sok évtizedes és ma is folytatódó széles körü empirikus és elméleti pedagógiai, szociológiai, közgazdasági kuta- 
tások eredményeitől és következtetéseitől - az oktatás és képzés minöségi, tartalmi, szervezeti aspektusaival és hatékonyságával kapcsolatos kérdéseket nem egyszerüen az oktatás vagy a pedagógia gyakran szüknek bizonyuló belső logikájából kiindulva, egyfajta hagyományos felfogásban közelítik meg. Arra keresik és adják meg a válaszokat, hogy:

1) figyelembe véve az Unió egészének és az egyes tagállamoknak a fejlettségét, a globalizáció, a tudásalapú társadalom építésének viszonyai között közösségi szinten mi az oktatás és képzés helye, szerepe az EU nemzetközi versenyképességének erösítésében;

2) konkrétan milyen számszerüsíthető mennyiségi és minőségi követelményeknek kell a szektornak megfelelnie ahhoz, hogy a jelen viszonyok között a lehetô leghatékonyabban hozzájáruljon a munkanélküliség, a társadalmi kirekesztődés leküzdéséhez, a társadalmi-gazdasági kohézió erősítéséhez; milyen kapcsolódások léteznek e szakmapolitikai szektorok között;

3) közösségi szinten melyek lehetnek a legalkalmasabb, legcélravezetőbb eszközei, módszerei a közösen azonosított célok megvalósításának, melyek lehetnek a célok megvalósítását szolgáló közösségi támogatás formái, és mekkora lehet annak volumene?

E kérdések napirendre kerülése vitán felül bizonyítja, hogy az oktatás, képzés szerepének, a közösségi politikákon belüli helyének a megítélésében egy új korszak köszöntött be. Ezúttal már nem csupán a közösségi oktatáspolitika stratégiai céljainak újszerủ megfogalmazásáról van szó, hanem megtörtént a stratégia artikulálása, azaz a megvalósítását szolgáló konkrét mennyiségi és minöségi célok kijelölése, továbbá a célok elérését biztosítani hívatott tetemes nagyságrendü közösségi támogatási források azonosítása, oly módon, hogy az egyidejüleg ösztönzöleg hasson a közösen elhatározott célok valóra váltását segitő nemzeti erőforrások mozgósítására is.

A közösségi támogatási források érdemleges növelésére annál inkább is szükség volt, mert a kilencvenes évtized közepéig közvetlenül az oktatással, képzéssel (és ifjúságpolitikával) kapcsolatos kiadásokra az EU teljes költségvetésének mindössze 0,3-0,5\%-a jutott. Ezek az összegek pedig, szerény nagyságrendjüknél fogva nem lehettek alkalmasak az oktatás, képzés területén megfogalmazott nagyszabású közösségi fejlesztési elgondolások valóra váltásának ösztönzésére, ill. finanszírozására.

Magától értetődően megfogalmazódott, hogy a valamennyi tagállamban és közösségi szinten elötérbe került foglalkoztatáspolitikai, szociális gondok, feszültségek leküzdése, csakúgy, mint a nemzetközi gazdasági, tudományos „küzdőtéren” is versenyképes tudásalapú társadalom teljes körü kiépítése érdekében nem csupán a tagállamoknak kell fokozott eröfeszítéseket tenni az oktatási és képzési rendszerek fejlesztése, tartalmi megújítása, minőségének javítása tekintetében, hanem ezen célok valóra váltását az Európai Uniónak és intézményeinek a közösségi politikai célok artikulált megfogalmazásával, s számottevő pénzügyi forrásokkal is támogatnia, segítenie kell, továbbá ezeken a területeken közvetlenül is ösztönöznie, szerveznie kell a tagállamok közötti együttmúködést, tapasztalat- és információcserét. Mindez egyik legfontosabb elöfeltétele annak, hogy az Unió elérhesse a 2000. már- 
ciusi Lisszaboni csúcsértekezleten kitúzött stratégiai célját, nevezetesen, hogy a Közösség 2010-re a világ legversenyképesebb és legdinamikusabban fejlödö térségévé váljon.

Az EU végeredményben a Strukturális Alapokban, mindenekelőtt az Európai Szociális Alapról (ESZA) és az Európai Regionális Fejlesztési Alapról (ERFA) szóló alapdokumentumokban fogalmazta, ill. jelölte meg a Közösség által „felvállalt” oktatási, szakképzési célokat és a megvalósításukat segítő finanszírozási forrásokat. ${ }^{\prime}$ Ez nagyságrendekkel megnövelte a fejlesztésre rendelkezésre bocsátható közösségi pénzügyi eszközöket.

A továbbiakban a tanulmány érdemben elsősorban azzal kíván foglalkozni, hogy milyen formában támogatja, ill. támogathatja az Európai Szociális Alapª az oktatási, képzési rendszerek fejlesztését, korszerüsítését, illetve a rendszerek szereplöinek (pedagógusok, oktatók, tanulók, diákok) oktatását, képzését, továbbképzését, valamint, hogy a tagállamok mindezidáig milyen módon hasznosították az ESZA-t az oktatási, képzési rendszer fejlesztésére. Ezzel összefüggésben rövid vizsgálat tárgyává tesszük, hogy Magyarország számára az uniós csatlakozás nyomán milyen pótlólagos potenciális fejlesztési források nyílhatnak meg az oktatás, képzés területein, valamint, hogy ez ideig a közösségi erőforrások igénybevételére kidolgozott Nemzeti Fejlesztési Terv e tekintetben milyen konkrét elgondolásokat tartalmaz.

\section{Az oktatás és a szakképzés helye, szerepe az Európai Szociális Alap céljainak a megvalósításában}

Az Európai Szociális Alap (ESZA) mintegy négy évtizedes története jól példázza a humánerőforrás-fejlesztés tartalmával és jelentőségével kapcsolatos közösségi felfogás alakulásának irányát és dinamikáját. Az alap tevékenysége már a kezdetektöl fogva közvetlenül kapcsolódott a képzéshez, hiszen a Római Szerződés az ESZA egyik kiemelt feladatát a munkavállalók szakmai és földrajzi mobilitását segító át- és továbbképzések támogatásában jelölte meg. A támogatás azonban csak a felnöttképzésben érintett aktív munkavállalók viszonylag korlátozott célcsoportját ölelte fel, s nem terjedt ki pl. sem a munkanélkülivé vált munkavállalókra, sem az iskolából kikerült szakképzetlen fiatalokra, vagy éppenséggel figyelmen kívül hagyta a tartós munkanélkülieket, a gazdasági, technológiai változások okán munkanélküliséggel fenyegetett, s a társadalmi kirekesztődés veszélyeinek különösen kitett különböző társadalmi, etnikai csoportokat. Annak idején gyakorlatilag fel sem merülhetett, hogy a kizárólagosan nemzeti hatáskörbe tartozó oktatási ${ }^{3}$ rendszerek (köz- és felsőoktatás), valamint azok szereplöi (tanulók, diákok, pedagógusok, oktatási döntéshozók stb.) az ESZA forrásaiból közvetlenül közösségi támogatásban részesüljenek, és ezáltal ilyen vagy olyan formában tulajdonképpen a közösségi szabályozás alanyaivá váljanak.

A Közösség belső gazdasági-társadalmi viszonyaiban bekövetkezett kedvezötlen folyamatok, az EU gazdaságilag elmaradottabb államokkal történt kibövülése, valamint az élezôdő nemzetközi gazdasági versengés együttes hatására került sor az 
ESZA sorozatos reformjaira $(1971,1977,1988,1993$, 1999). Ezek a reformok mintegy visszatükrözve a humán erőforrások fejlesztésének stratégiai jelentőségéről vallott mértékadó tudományos nézetek fokozatos térhódítását és közösségi szintü befogadását - egyfelöl fokozatosan növelték az ESZA rendelkezésére bocsátott közösségi források nagyságrendjét, másfelől szélesítve és gazdagítva tevékenységi körét lépésröl-lépésre az ESZA középpontjába helyezték a gazdasági-társadalmi kohézió erősítésére hívatott ún. aktív munkaerö-piaci beavatkozásokat, köztük az oktatási, képzési tevékenységek támogatását. Innen már csupán egy lépés volt az oktatási és képzési rendszerek fejlesztésének önálló fejlesztési célként, ún. tevékenységi területként történő támogatása.

E nagy horderejủ és újszerủ szemléletváltás alátámasztására 1999 tavaszán az EU állam és kormányföinek berlini találkozóján született döntés arról, hogy az 1997. évi Amszterdami Csúcsértekezleten megfogalmazott Európai Foglalkoztatási Stratégia céljainak megvalósítását kitüntetetten szolgálni hívatott Európai Szociális Alap forrásait ezentúl nem csak szigorúan foglalkoztatáspolitikai célokra, hanem közvetlenül az oktatási, képzési rendszerek fejlesztésére is igénybe lehet venni. Arról is döntés született, hogy a különbözö közösségi fejlesztési források (Strukturális Alapok, Kohéziós Alap, közösségi oktatási, szakképzési akcióprogramok, $\mathrm{K}+\mathrm{F}$ keretprogramok stb.) összehangolt felhasználása révén fokozottabban biztosítani kell a Közösség által finanszírozott programok szinergikus, azaz egymást kölcsönösen erösítő és kiegészítö hatását ${ }^{4}$.

Rendkívül jelentös nagyságrendű közösségi források allokálásáról született döntés, hiszen az új programozási időszak (2000-2006) hét esztendejében a strukturális politika rendelkezésére álló 195,01 Mrd euró nagyságrendü közösségi támogatási alapok kereken 1/3-át, azaz mintegy 60 Mrd eurót szántak az Európai Szociális Alap által támogatott tevékenységek finanszírozására.

\section{Az Európai Szociális Alap feladatai az oktatás, képzés terén a 2000-2006-os programozási idöszakban}

Az Európai Szociális Alap 1960-ban történt létrehozásától kezdve - a munkavállalók szakmai, földrajzi mobilitását segítendö - kiemelt figyelmet fordított a munkavállalók szakmai át- és továbbképzésére, ám nem foglalkozott átfogóan az oktatás és képzés foglalkoztatáspolitikai implikációival, még kevésbé biztosított célzottan közösségi forrásokat az oktatási és képzési rendszerek korszerüsítésére. Az ESZA mintegy négy évtizedes történetében, a 2000-2006 közötti idöszakra vonatkozó tanácsi rendeletben ${ }^{5}$ fogalmazódik meg elsỏ ízben önálló célként és karakteresen az oktatási és a szakképzési politikák és rendszerek korszerúsítésének kiemelt támogatása. A Rendelet 2. cikkének c. pontja értelmében az ESZA támogatja az „oktatás és a szakképzés fejlesztését”, továbbá ,az egész életen át tartó tanulás részeként a munkaerőpiacra jutást és munkaerő-piaci integrációt, a foglalkoztathatóság javítását, valamint a munkahelyi mobilitást". A Rendelet 3. cikke konkrétan is 
felsorolja az oktatás és szakképzés területén az Alap által támogatott tevékenységeket. Így többek között, külön kiemeli:

- a kötelezö iskoláztatás ( alapképzés és oktatás) fejlesztését,

- a pedagógusok, oktatók, szakoktatók továbbképzését,

- a tanoncképzést,

- a pályaorientáció és tanácsadás fejlesztését,

- a vállalkozások és az oktatási, szakképzési és az idevágó kutatásokkal foglalkozó intézmények közötti kapcsolatok fejlesztését,

- a kutatóhelyeken a posztgraduális jellegü továbbképzéseket vezetők és müszaki szakemberek számára.

A Rendelet nem hagy kétséget abban a tekintetben, hogy az oktatási, képzési tevékenységek támogatásának egyértelmủ célja az ESZA által megfogalmazott átfogó célkitűzések megvalósításának segítése. ${ }^{6}$

Az oktatási-képzési rendszerek fejlesztésének támogatása önálló célként (tevékenységi területként) történt megjelenése természetesen a legkevésbé sem jelenthette azt, hogy az ESZA rendeletben kiemelt további négy, ún. tevékenységi területnek, nevezetesen

1) az aktív munkaerö-piaci politikák támogatásának,

2) a kirekesztés elleni küzdelem jegyében az egyenlő esélyek biztosításának a munkaeröpiacra történö belépés terén,

3) a vállalkozói készségek, a munkaerő és a munkaszervezetek alkalmazkodó- és innováció-képessége fejlesztésének,

4) továbbá a nők munkaerö-piaci részvételi esélyei javításának ${ }^{7}$

ne lennének rendkívül komoly relevanciái az oktatás és a képzés szempontjából. Más szóval a tág értelemben vett oktatás és képzés rendelkezésére álló eszközök és intézmények változatos és széles skálája igen hatékonyan képes segíteni valamenynyi tevékenységi terület vonatkozásában a megfogalmazott szakpolitikai célok megvalósítását, sőt, az oktatási, szakképzési rendszerek fejlesztése minőségének javítása tulajdonképpen a Közösség foglalkoztatás-stratégiai céljainak valóra váltására szolgáló „eszköztár” szerves és nélkülözhetetlen, semmivel sem helyettesíthető tartozéka.

A nők munkába állítását, munkaerő-piaci esélyeik javítását (5. tevékenységi terület) csakúgy, mint a kirekesztődés elleni küzdelmet (2. tevékenységi terület) igen hatékonyan és közvetlenül segítheti az iskoláskor elötti oktatás (óvoda) fejlesztése és kiterjesztése. Az iskolai lemorzsolódás csökkentésének pedig a fiatalok munkaerö-piaci (és társadalmi) integrációja szempontjából (is) vitális jelentősége van. Az is teljesen nyilvánvaló, hogy a munkaerö képzettségének javítása elengedhetetlen feltétele a munkavállalók alkalmazkodóképessége, szakmai, földrajzi mobilitása növelésének (4. tevékenységi terület). A képzés, továbbképzés különböző formáinak alkalmazása nélkül ugyanis el sem képzelhetỏ a munkavállalók és a vállalatok alkalmazkodóképességének javítása. 
E néhány kiragadott példa is bizonyítja az oktatás, szakképzés és a foglalkoztatáspolitika közötti szoros kölcsönös kapcsolatot, hiszen az ún. aktív foglalkoztatási eszközök zöme közvetlenül, vagy közvetve oktatási, képzési jellegü.

A Tanács 2001-ben külön Állásfoglalásban ${ }^{8}$ is felhívta a figyelmet az oktatás és szakképzési politika fontosságára az Európai Foglalkoztatási Stratégia szempontjából. Az Állásfoglalás hangsúlyozza az oktatáspolitika össztársadalmi kontextusba ágyazásának fontosságát, s ennek kapcsán megerösíti az európai oktatási és képzési rendszerek jövendő konkrét céljairól szóló jelentésben és az annak alapján készült ún. részletes munkaprogramban (Report from the Education... 2001; Detailed Work Programme... 2002) megfogalmazott hármas célkitüzést, nevezetesen: az oktatási és képzési rendszerek hatékonyságának javítása (1), az oktatási és a képzési rendszerekhez történö széles körü hozzáférés megkönnyítése (2), az oktatási képzési rendszerek nyitottá tétele (3), és a foglalkoztatási stratégiában megjelölt célok egymást feltételező és kölcsönösen kiegészító jellegét.

\section{Az éves Foglalkoztatáspolitikai Irányvonalak és az oktatás, képzés}

Az oktatás és szakképzés stratégiai szerepével és a szakpolitikák közötti koherencia szükségességével kapcsolatos közösségi felfogás megerösítését jelentették az 1998 óta évente közreadott ún. Foglalkoztatáspolitikai Irányvonalakban 1999 óta mind nyomatékosabban megfogalmazódó elvárások. Az Irányvonalak ugyanis egyfajta vezérfonalként, elvi és gyakorlati iránymutatásként szolgálnak a tagállamok számára a foglakoztatási stratégia céljainak nemzeti keretek közötti megvalósításának konkrét programját tartalmazó ún. éves Nemzeti Akcióprogram (NAP) elkészítéséhez, csakúgy, mint a NAP-ok végrehajtásának közösségi szintü értékeléséhez.

Az Irányvonalakba 2001-től gyakorlatilag beépültek a Lisszaboni Csúcsértekezlet döntései nyomán a Közösség oktatáspolitikai gyakorlatának újszerủ vonásai, noha pl. az. egész életen át tartó tanulás ügye már 1999 óta szerepel az irányvonalakban. A 2001. évi Foglalkoztatáspolitikai Irányvonalakban ${ }^{9}$ azonban első ízben fogalmazódott meg horizontális, azaz valamennyi (4), ún. pillér alá sorolt konkrét fejlesztési célban megjelenítendő feladatként az egész életen át tartó tanulás stratégiája ${ }^{10}$ alkalmazásának követelménye. Ez egyértelművé tette, hogy a Tanács felfogása szerint az egész életen át tartó tanulásnak mind a négy pillérben (foglalkoztathatóság, alkalmazkodóképesség, vállalkozói készség javítása, nök és a férfiak közötti esélyegyenlöség elömozdítása) megjelölt célok elérésében érdemi szerephez kell jutnia.

Az Irányvonalakat felvezető Tanácsi határozat külön is felhívja a figyelmet arra, hogy az Irányvonalak gyakorlati megvalósitásának menetében - azaz a NAP-okban - a tagállamoknak törekedniük kell a Lisszaboni Csúcsértekezlet döntéseiben kiemelt oktatáspolitikai prioritásokkal (az alapfokú, a közép- és a felsőoktatási rendszerek, továbbá a továbbtanulás és -képzés fejlesztése oktatási és képzési rendszereinek fejlesztése, az emberi erőforrások fejlesztésére fordított éves kiadások lényeges növelése stb.) való összhang és konzisztencia biztosítására. 
Ha sorra vesszük az Irányvonalak négy pillére alatt megfogalmazott célokat, lépten-nyomon olyan konkrét feladatokba ,ütközünk”, amelyek megvalósításában az oktatási-képzési rendszerekre számottevő feladatok hárulnak. Íme néhány példa:

A foglalkoztathatóság növelése (I. pillér)

Mind a tartós munkanélküliek munkaerő-piaci visszaillesztése, mind az idősek aktív támogatása, illetve a munkaerỏ-piaci igények teljesebb kielégítése, valamint a diszkrimináció elleni küzdelem is, az „aktív intézkedések” részeként számos oktatás-képzési természetủ tevékenységet feltételez.

Az alkalmazkodókészség fejlesztése és a munkahelyteremtés (II. pillér)

Hasonlóképpen, közvetlenül kapcsolódik az oktatás és képzés a II. pillér alatt megfogalmazott célokhoz. Mind az új vállalkozások alapításának megkönnyítésére, mind a tudásalapú szektorokban új munkahelyek létrehozására, mind a helyi foglalkoztatási lehetőségek növelésére vonatkozó célok megvalósításának vannak oktatási-képzési vonzatai.

A vállalkozások és alkalmazottaik alkalmazkodókészségének ösztönzése (III. pillér)

Hatványozottan igaz ez a III. pillér keretében megfogalmazott konkrét célkitúzések esetében, mind a munkahelyi szervezet rugalmasságának növeléséhez, mind a vállalatokon belül az új technológiák meghonosításához az oktatás és képzés eszközrendszerének az intenzív igénybevételével vezet az út.

Férfiak és nök közötti esélyegyenlöség erösitése (IV. pillér)

Tulajdonképpen még a IV. pillérnek is lehetnek, söt vannak is konkrét oktatási, képzési összefüggései, hiszen az iskolai nevelésben folyamatosan figyelmet kell szentelni a nemek közötti egyenlö esélyek kérdésének. Emellett a többi három pillér keretei között megvalósuló oktatási, képzési programok lebonyolításakor, a gyakorlatban mindenkor kötelezỏ érvényesíteni a nemek közötti egyenlő esélyek elvét.

Természetesen, az egész életen át tartó tanulás szemléletének keretei között megfogalmazott, csakúgy, mint az egyes irányvonalak gyakorlati céljainak megvalósítását szolgáló oktatási-szakképzési fejlesztések tervezése és kivitelezése során meszszemenően figyelembe kell venni az Irányelvekben megfogalmazott olyan egyéb általános szempontok érvényesítését is, mint a regionalizmus, vagy a szociális partnerekkel történő folyamatos egyeztetés.

A 2002. évi Foglalkoztatási Irányvonalak" tovább megy a 2001. évi Irányvonalak által megkezdett úton. Igen szemléletesen érzékelteti az oktatás, képzés, illetve a foglalkoztatáspolitika és a társadalmi, gazdasági kohézió közötti szoros kapcsolódásról a Közösség és a tagállamok között e téren kialakítandó együttmúködés munka- és felelősség-megosztás jellegéröl, tartalmáról vallott uniós szintű gondolkodás fejlődésének irányát .

Egyfelöl - a 2001. évi Irányvonalakhoz hasonlóan - önálló, ún. horizontális célkitúzésként igényli ${ }^{12}$, hogy a tagállamok átfogó és koherens stratégiát dolgozzanak ki az egész életen át tơrténö tanulás szemléletének a megvalósítására. Felszólítja a tagállamokat, hogy tủzzenek ki konkrét nemzeti célokat a humán erőforrásokba 
történő beruházások növelésére, az oktatás, képzés fejlesztésére, s folyamatosan kísérjék figyelemmel a célok megvalósításának menetét.

Másfelöl, a tervezet már nem éri be az európai oktatási és képzési rendszerek korszerủsítése fontosságának, az egész életen át tartó tanulás átfogó fejlesztése szükségességének hangoztatásával, hanem a korábbiaknál lényegesen konkrétabban megjelöli a támogatható tevékenységek körét, sőt számszerüsített fejlesztési célokat is meghatároz az oktatás-képzés területén. A dokumentum a foglalkoztatási stratégia keretei között a támogatható tevékenységek és fejlesztési célok rendkívül gazdag és sokszínü „választékát” vonultatja fel. Ezzel lehetőséget biztosít valamennyi tagállam számára, hogy saját adottságaiból, lehetőségeiből és igényeiből kiindulva határozza meg az ESZA források specifikus nemzeti fejlesztési célokra történő felhasználását az oktatás, képzés területein.

A Foglalkoztathatóság javítása címet viselö I. fejezet (a foglalkoztatási stratégia ún. 1. pillére) kiemelt figyelmet szentel az egész életen át tartó tanulás szellemében az új munkaerő-piaci igényeknek megfelelö készségek, szakképzettség kialakításának. Hangsúlyozza, hogy a ,hatékony és jól müködő, s a munkaerö-piaci igényekre reagálni képes oktatási és képzési rendszernek kulcsszerepe van" a tudásalapú társadalom feltételeinek megteremtésében, a foglalkoztatás szintjének és minőségének a javításában. Ezzel összefüggésben pl. nyomatékkal szól a színvonalas alapképzés, a tananyagfejlesztés, a pályaorientáció és tanácsadás, az iskolai lemorzsolódás csökkentésének, a tanulási nehézségekkel küzdö fiatalok támogatásának fontosságáról. Rámutat továbbá a felnöttképzésben részt vevő felnöttkorúak (25-64 év közöttiek) - ideértve tehát az idősebb munkavállalókat is - aránya növelésének a jelentőségére, ezen belül a felnött írástudatlanság felszámolásának, a munka melletti át- és továbbképzés, $\mathrm{s}$ a helyi multifunkcionális tanulási központok kialakításának fontosságára. Elengedhetetlennek tartja a szociális partnerek bevonását a célok kijelölésébe, azok megvalósítási menetébe. Kiemelt feladatként fogalmazza meg valamennyi tagállam számára az oktatásból és a képzésböl kirekesztődött, vagy a kirekesztődés veszélyének kitett hátrányos helyzetủ egyének, társadalmi csoportok integrálását, különös tekintettel a fogyatékkal élökre, a nemzeti kisebbségekre, a migráns munkavállalókra.

Konkrét célként jelöli meg a tagállamok számára a középiskolai végzettséggel nem rendelkezö 18-24 életév közötti fiatalok számának 50\%-kal való csökkentését 2010-ig, valamennyi iskola számára Internet hozzáférés biztosítását 2002 végéig, valamint azt, hogy valamennyi pedagógus megszerezze a korszerủ számítástechnikai eszközök használatához és alkalmazásához szükséges ismereteket és készségeket, továbbá a munkanélküliek legalább $20 \%$-a részére szervezett oktatási, képzési lehetöség biztosítását, mindenekelött a számítástechnika területén.

A tervezet további fejezetei (II. pillér: Vállalkozói készségek fejlesztése, III. pillér: Munkavállalók és vállalatok alkalmazkodóképességének javítása, IV. pillér: Férfiak és nők esélyegyenlöségének erősítése) is bővelkednek olyan célokkal, feladatokkal, amelyek kivitelezése és megoldása elsősorban az oktatási, képzési rendszerekre hárul. 
A Tanács, mintegy tovább artikulálva határozatát, az egyes tagállamok címére konkrét ajánlásokat is megfogalmazott a foglalkoztatási stratégia nemzeti keretek között megvalósítandó időszerủ feladataira vonatkozóan ${ }^{13}$. Ezen ajánlás 14. pontja általánosságban újólag kiemeli az egész életet átfogó oktatás és képzés koherens programja kidolgozásának szükségességét, s megvalósítása érdekében sürgeti valamennyi érintett szereplö bevonásának (állam, vállalkozások, egyén, civil szféra, szociális partnerek stb.) bekapcsolásának fontosságát.

Ma már elmondható, hogy a tág értelemben vett oktatás, képzés az egész életen át tartó tanulás stratégiájának „,képében” immár az Unió foglalkoztatáspolitikai koncepciójának és gyakorlatának szerves részévé vált. Ilyenformán az Európai Foglakoztatási Stratégia megvalósítását szolgáló Európai Szociális Alap forrásai minden olyan esetben támogathatják az oktatási és képzési rendszerek fejlesztését, ha azok a munkaeröpiac jobb müködését, az egyének foglalkoztathatóságának javitását szolgálják.

\section{A Foglalkoztatáspolitikai Irányvonalak gyakorlati végrehajtásának tapasztalatai a tagállamokban az oktatás, képzés terén}

A Bizottság által 2001 legelején készített elözetes összesítés arról tanúskodik, hogy a tagállamok a nemzeti foglalkoztatási stratégiájuk keretében kiemelt fontosságot tulajdonítanak az egész életen át tartó tanulás támogatásának: a 2000-2006 közötti tervezési periódusban a Nemzeti Foglalkoztatási Akciótervek (NAP) keretében az ESZA rendelkezésére álló mintegy 60 Mrd euró 20\%-át (12 Mrd eurót) tervezik majd az egész életen át tartó tanulást szolgáló programok finanszírozására forditani (Communication from the Comission... 2001).

\section{A 2000. évi Irányvonalak végrehajtása és az oktatás, képzés}

Az Európai Bizottság az ESZA történetében elóször 2001 tavaszán két külön jelentésben is elemezte (European Report... 2001 a; 200lb), hogy a tagállamok 2000. évi Nemzeti Foglalkoztatási Akcióterveiben (NAP) milyen konkrét tevékenységek formájában jelent meg az oktatás és a szakképzés támogatása, továbbá azt, hogy milyen mértékben és formában jelenítették meg nemzeti akcióterveikben az Irányvonalakban és egyéb kiemelt közösségi dokumentumban az oktatási, és képzési rendszerek fejlesztésével kapcsolatban megfogalmazott elvárásokat. A terjedelmes jelentések több figyelemre méltó tanulsággal is szolgálnak. Igen szemléletes módon rávilágítanak az oktatás és képzés valamint a foglalkoztatáspolitika közötti szoros és sokrétú kapcsolódásra, $s$ az Európai Tanács idevágó lisszaboni döntéseire hivatkozva megerősítik, hogy az egész életen át tartó tanulást a Foglalkoztatási Irányvonalak egyik kiemelt prioritásának kell tekinteni.

A Bizottság a tagállamok jelentéseinek kritikus elemzése alapján arra a következtetésre jutott, hogy a tagállami beszámolók „kevés konkrét intézkedést tartalmaznak az oktatás általános minőségének javítására”, továbbá, hogy „,a tagállamok többsége továbbra sem rendelkezik olyan koherens oktatási, képzési stratégiával, amely szerves egységbe fogná össze az egyes oktatási, képzési rendszereket, s elömozdítaná a 
formális és informális tanulás ügyét" (European Report... 2001b). Mindazonáltal a Bizottság elismeri, hogy a nemzeti foglalkoztatási akciótervek számos újszerủ kezdeményezést, intézkedést tartalmaznak az iskolai lemorzsolódás csökkentésére, a munka melletti olyan képzések ösztönzésére, amelyek az új technológiák, a szakmai készségek és ismeretek elsajátítását, a szakképzettségek elismerését támogatják.

A jelentések részletesen ismertetik a 2000. évi Foglalkoztatási Irányvonalak kifejezetten, vagy elsődlegesen az oktatáshoz, képzéshez kapcsolódó irányvonalainak megvalósítására hozott tagállami intézkedéseket. Mindenekelött a 6. (az egész életen át tartó tanulás megvalósítását szolgáló intézkedések), a 7. (az oktatási rendszerek javítása az iskolai lemorzsolódás csökkentése érdekében), a 8. (a tanulási és szakképzési rendszerek korszerüsítése az új technológiák alkalmazását segítő készségek és szakismeret elsajátítására), a 11. (a vállalkozó készségeket szolgáló képzések fejlesztése) a 15. és 17. ( a vállalkozásokon belüli képzések elömozdítása a szociális partnerek támogatásával és pénzügyi ösztönzök alkalmazásával) intézkedések jelentik ezt a kört. Az irányvonalak oktatási, képzési vonatkozásainak gyakorlati megvalósításáról szóló jelentések számos, a magyar viszonyok között adaptálható megoldásokat, konkrét intézkedéseket tartalmaznak.

A 2001. évi Foglalkoztatáspolitikai Irányelvek végrehajtásának értékelésével foglalkozó, minap nyilvánosságra hozott 2002. évi Foglalkoztatáspolitikai Jelentés első változatában (Communication from the Commission... 2002) külön is kitér az egész életen át tartó tanulás „,horizontális célkitűzésének” a megvalósitása terén 2001-ben elért eredményekre. A Bizottság összességében úgy véli, hogy a tagállamok a beszámolási időszakban ,előrehaladást értek el az egész életen át tartó tanulás stratégiájának kidolgozásában, ám a stratégia teljes körủ végrehajtása még várat magára" (Communication from the Commission... 2002). A jelentés ezzel összefüggésben kiemeli a foglalkoztatáspolitika és az egész életen tartó tanulás stratégiái közötti koherencia némi javulását, de változatlanul hiányolja az oktatási és képzési rendszerekböl a munkaerőpiacra történő átmenet kérdéseinek komplex kezelését. A jelentés kedvezö fejleménynek ítéli, hogy számos tagállam növelte a humán erőforrásokba eszközölt befektetések nagyságrendjét, továbbá, hogy indikátorok alkalmazásával méri az oktatás különbözö szintjeiben való részvétel és a teljesítmények szintjét. Ugyanakkor aggodalommal szól arról, hogy noha a 25-84 év közötti felnött korcsoportban érzékelhetöen növekedett az oktatásban, képzésben résztvevök aránya (az 1997. évi 5,8\%-ról 2001-ben 8,4\%-ra), túlságosan nagyok a kủlönbségek a képzésben történő részvétel arányait tekintve a képzettség szintje és az életkor szerint. A dokumentum ezért a tagállamoktól erőteljesebb intézkedéseket vár annak érdekében, hogy sikerüljön elérni a lakosság alacsonyabb képzettségủ és tanulásra kevésbé hajlamos csoportjainak a képzésbe történő bekapcsolódását. A jelentés önálló táblázatba foglalva külön is értékeli a tagállamok 2001. évi teljesítményét az egész életen át tartó tanulás stratégiájának kidolgozása és megvalósítása terén.

Összességében úgy tünik, hogy a Lisszaboni Csúcsértekezleten elfogadott humánerőforrás-fejlesztési politika, tengelyében az egész életen át tartó tanulás koncepciójával, ha fokozatosan is, de immáron szervesen beépül a Közösség foglalkoztatáspolitikai stratégiájába. 


\section{Az oktatás-szakképzés és Magyarország uniós csatlakozása}

Az Európai Unió, mint fentebb láttuk, az elmúlt néhány esztendỏ során lépésrỏl lépésre újrafogalmazta az oktatással és képzéssel kapcsolatos közösségi politika cél- és eszközrendszerét, s ehhez a tagállamok együttmüködése érdekében hozzálátott új keretek kialakításához. Elöre lehet látni, hogy ezek a fejlemênyek a csatlakozás után Magyarország elé meröben új követelményeket állítanak, amelyek megismerésére és teljesítésére jó elöre fel kell készülni. Ugyanis ezen a területen az együttmüködés várható további elmélyítése, amely - a tagállamoknak az oktatás tartalmára és szervezeti felépítésére vonatkozó, s az EU-ról szóló, szerződésben rögzített kizárólagos kompetenciájának sérelme nélkül - a Közösség által megfogalmazott oktatáspolitjkai stratégiához történő alkalmazkodáson túlmenóen magában foglalja majd konkrét mennyiségi és minőségi oktatási, képzési célok nemzeti keretek között vállalt módozatainak vállalt ütemezés szerinti megvalósítását, valamint az eredmények közös értékelését, minöségileg új feladatok elé állítja az oktatás-képzés kérdéseiért felelós kormányzati szerveket, szakmai testületeket ${ }^{14}$.

Aligha vitatható, pl., hogy az egész életen át tartó tanulás európai stratégiájának elvei és kialakulóban lévő tagállami gyakorlata iránymutató lehet a hazai oktatás, képzés napirenden lévő korszerüsítéséhez. E stratégia hazai viszonyokra történő adaptálását szolgáló koherens politika kimunkálása és a gyakorlatba történó átültetése azonban nem egyszerúen további szellemi, anyagi erőforrások mozgósítását igényli majd, hanem sok tekintetben újszerú együttgondolkodást és cselekvést követel az érintett kormányzati szervektől, szakemberektől, társadalmi és szakmai szervezetektől, sőt a társadalom egészétỏl.

\section{A magyar oktatásügy és a Strukturális Alapok}

Az uniós csatlakozás kapcsán a magyar oktatásügy számára talán az egyik legnagyobb kihívást az jelenti, hogy miképpen lesz képes az ágazat hatékonyan élni az EU Strukturális Alapjai - az Európai Szociális Alap (ESZA) és az Európai Regionális Fejlesztési Alap (ERFA) - által finanszírozott átfogó fejlesztési programok végrehajtásában való részvétel lehetőségeivel. Más szóval, miképpen tud majd az oktatásügy a legeredményesebben hozzájárulni a Strukturális Alapok által kiemelten támogatott nemzeti fejlesztési célok (társadalmi-gazdasági kohézió erősítése, a versenyképesség, a foglalkoztathatóság javítása stb.) megvalósításához, egyidejűleg szolgálva saját folyamatos megújulását, fejlödését és gyarapodását.

Bizonyos, hogy az Alapok révén Magyarország olyan addicionális fejlesztési forrásokhoz jut majd, ami kivételesen kedvezỏ feltételeket kínál a magyar közoktatás-, szakképzési és felsőoktatás-politika cél- és eszközrendszerének a közösségi elvárásoknak (is) megfeleló új, elóremutató elemekkel való gazdagítására. Ugyanis, az EU strukturális politikája által megfogalmazott és a jelenlegi magyar oktatáspolitika számára részben újszerú szakmapolitikai feladatokkal, követelményekkel egyidejüleg rendelkezésre állnak majd a teljesítêsükhöz szükséges pótlólagos források. 
(Gondoljunk csak pl. az egész életen át tartó tanulás stratégiájának hazai viszonyokra történö adaptálásából és a gyakorlatba történö átültetéséböl fakadó szerteágazó elönyökre.)

Ha figyelembe vesszük továbbá, hogy az oktatásügy fejlesztése számára a hazai erőforrások számottevő bővítésének (mindenekelött a GDP-ből és a költségvetésböl való részesedési arány lényeges növelésének) objektív gazdasági, költségvetési és tegyük hozzá politikai korlátjai, akadályai vannak és lesznek a jövőben is, nem lehet túlbecsülni a szektor fejlesztése szempontjából a Strukturális Alapok addicionális forrásaihoz való teljes körü hozzáférés fontosságát. Ráadásul, a csatlakozás révén a források bővítésére éppen azokon a területeken (is) kínálkozik majd valós lehetőség, amelyeken a hazai ráfordítások növelésének nem egyszer politikailélektani korlátjai is vannak ${ }^{15}$, s amelyek viszont kifejezetten felértékelik az ágazat helyét és szerepét a társadalmi, gazdasági integráció, a felzárkóztatás, az esélyteremtés, a munkaerö alkalmazkodó képességének a javítása szempontjából. Ezekböl következöen, az Alapok hatékony kezelésére történő alapos és sokoldalú felkészülésnek az oktatásügy, de nemkülönben az ország egésze számára mind szakmapolitikai okokból, mind a fejlesztési forrásbővítési lehetőségek szempontjából kiemelkedö jelentősége van ${ }^{16}$.

\section{Az Oktatási Minisztérium helye és szerepe a kormányzat strukturális politikájában, az oktatás, szakképzés a Nemzeti Fejlesztési Tervben}

Az Oktatási Minisztérium, mint a közoktatás, szakképzés, felsőoktatás, kutatásfejlesztés irányításáért felelős tárca mindenkor a humáneröforrás-fejlesztési kormányzati politika formálásának és kivitelezésének természetes, magától értetődő, egyben megkerülhetetlen tényezője.

Szakmailag, politikailag soha nem is képezte vita tárgyát, hogy az ország versenyképességének javításában, a társadalmi-gazdasági kohézió erösítésében az ágazatnak kitüntetett szerepe van. ${ }^{17} \mathrm{Ez}$ azonban nem jelentette a tárca automatikus bekapcsolását a strukturális- és fejlesztéspolitika uniós kapcsolódásait érintő kormányzati munkálatokba. Ma már azonban elmondható, hogy minden vonatkozásban megteremtödtek az Oktatási Minisztérium aktív szerepvállalásának, a szektor részvételének alapvető jogszabályi és szakpolitikai garanciái a strukturális politika, ezen belül a foglalkoztatáspolitika, a regionális fejlesztés és a szociálpolitika valamennyi lényeges területén. A tulajdonképpeni feladat immáron a politika részleteinek kimunkálásához és gyakorlati kivitelezéséhez szükséges személyi, szervezetijogszabályi és tárgyi-pénzügyi feltételek megteremtése.

Az elsö jelentős lépést ebben a tekintetben a 2073/1999 (IV.23.) sz. Kormányhatározat elfogadása jelentette, amikor is az Európai Szociális Alap kezelése kapcsán az OM társfelelösi szerepet kapott. Ezt követöen lényegében a kormányzati politika minden szintjén egyetemesen elfogadottá vált az oktatási tárca tevőleges részvétele a strukturális politika hazai szakmai, jogi és adminisztratív kereteinek a kialakításában, s majdani végrehajtásában. 
Az Alapok kezelésére történö általános felkészülésben a kezdeti lendület 2001. folyamán különbözö, itt nem részletezendỏ okokból lelassult. Szinte minden területen az akkori kormány által megszabott határidőkhöz képest is jelentős lemaradás támadt. A 2002. év közepén lezajlott kormányváltás nyomán végrehajtott átszervezések is egy időre lelassították a felkészülést. 2002 utolsó 4-5 hónapjában azonban az időközben a Miniszterelnöki Hivatalban létrejött Nemzeti Fejlesztési Terv és EU-Támogatások Hivatalának irányítása és koordinálása mellett jelentösen felgyorsultak az EU források igénybevételének előfeltételét jelentő Nemzeti Fejlesztési Terv összeállítását, valamint az Alapok kezelésére hivatott hazai intézményrendszer kiépítésének elökészítését célzó munkálatok.

\section{A Nemzeti Fejlesztési Terv kidolgozása és az Oktatási Minisztérium}

Az OM kezdettől fogva részt vesz a Nemzeti Fejlesztési Terv (NFT) kidolgozására, szerkesztésére, valamint az ez irányú munkálatok koordinálására létrehozott Fejlesztéspolitikai Koordinációs Tárcaközi Bizottság és testületeinek a munkájában, továbbá a Foglalkoztatáspolitikai és Munkaügyi Minisztérium (FMM) koordinációja mellett a Humánerőforrás-fejlesztési Operatív Program (HEF OP) kidolgozásában. Különösen érdemi és kezdeményező szerepet vállalt az OM az Operatív Program intézkedéseinek a megfogalmazásában.

$\mathrm{Az}$ 1. ábra vázlatosan bemutatja az Oktatási Minisztériumnak a tervezömunka folyamatában és majdani végrehajtásában betöltött helyét.

\section{1. ÁBRA}

A Nemzeti Fejlesztési Terv szerkezete, az Irányító Hatóságok

(The Structure of the National Development Plan, the Manageing Authorities)

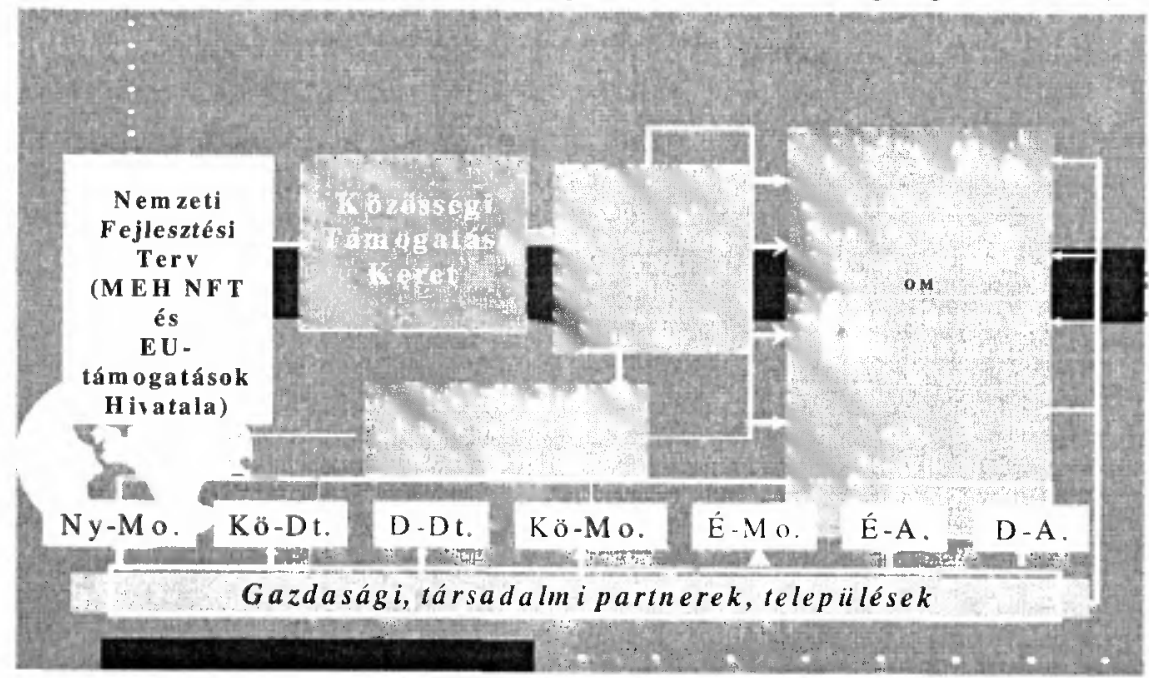

Forrás: Saját szerkesztés. 
A tervezö munka jelenlegi szakaszában (2002. december) elkészült a Nemzeti Fejlesztési Terv (NFT) elsö, a szakmai, társadalmi partnerekkel elözetesen egyeztetett változata ${ }^{18}$. Az NFT a SWOT analízis módszerének alkalmazásával tartalmazza az elmúlt 6-8 esztendö társadalmi, gazdasági folyamatainak elemzését, felvázolja a 2004-2006 közötti idöszakra érvényes fejlesztési stratégiát, s az abban képzett súlypontok, ún. konkrét célok (versenyképesség növelése [1], a foglalkoztatás javítása és humántőke fejlesztése [2], a környezet és az egészségügyi feltételek javítása [3]) mentén öt, ún. operatív programban konkrét intézkedésekre lebontva operacionalizálja azt ${ }^{19}$.

\section{2. ÁBRA}

Humäneröforrás-fejlesztési Operatív Program-Prioritások és intézkedések (Human Resource Development Operative Programme - Priorities and Measures)

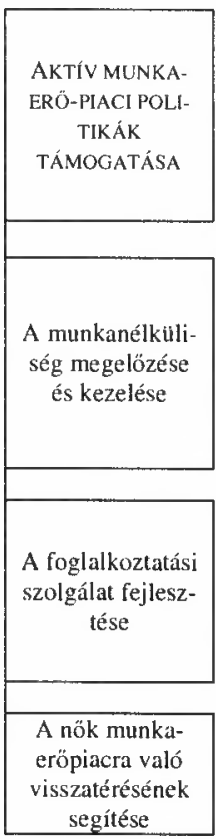

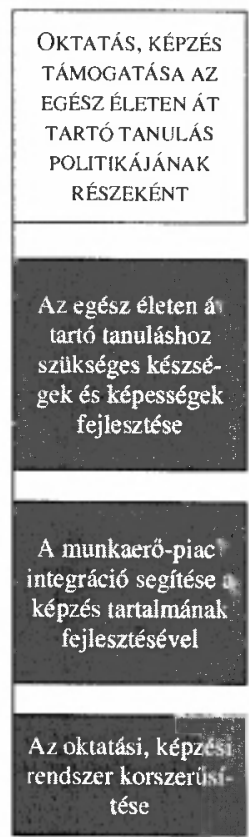

Hátrányos helyzetü lakosságcsoportok foglalkoztathatósáának javítása

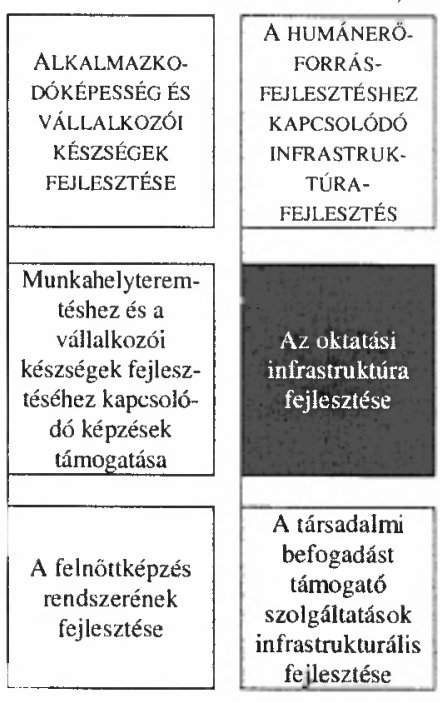

Forrás: Humánerőforrás-fejlesztés Operatív Program.

A foglalkoztatás javítását és a humántöke fejlesztését szolgáló cél elsődlegesen (de nem kizárólagosan) a Humánerőforrás-fejlesztés Operatív Program (HEF OP) intézkedéseire épít. A HEF OP-ban a 2004-2006 közötti időszakra szóló fejlesztési prioritások meghatározása - az Európai Bizottság illetékes fỏigazgatósága intencióinak megfelelően - alapvetöen az Európai Szociális Alapról (ESZA) szóló rendelet- 
ben vázolt ún. tevékenységi területek szerint történt ${ }^{20}$, míg az intézkedések azonosítására a helyzetelemzés tanulságainak az összegzése és az NFT konkrét céljainak a figyelembevétele alapján került sor. A HEF OP az NFT konkrét céljainak a megvalósításához

1) a népesség képzettségi szintjének az emelését,

2) a munkaerő foglalkoztathatóságának és alkalmazkodóképességének javítását,

3) a társadalmi esélykülönbségek csökkentését,

4) a humán szolgáltatások (oktatás, képzés, szociális ellátás) infrastruktúrájának a fejlesztését,

5) a hátrányos helyzetủ csoportok társadalmi és munkaerő-piaci beillesztésének előmozdítását szolgáló intézkedésekkel szándékozik hozzájárulni (2. ábra).

Ezen célok valóra váltásához a HEF OP - a Strukturális Alapok kezelésére vonatkozó közösségi elöírásokkal összhangban - az Európai Szociális Alap (ESZA) és részben az Európai Regionális Fejlesztési Alap (ERFA) forrásait kívánja igénybe venni (1. táblázat). Utóbbit a humán szolgáltatások infrastrukturális fejlesztéseihez. A HEF OP prioritásait, intézkedéseit, a végrehajtásukért elsödlegesen felelős tárcákat ismertető 2. ábra arról tanúskodik, hogy az OP kidolgozásáért felelős tárcák számottevő erőfeszítéseket tettek az intézkedések közötti koherencia megteremtése érdekében, és több olyan prioritás van, amelyek megvalósítását több tárca hatáskörébe tartozó intézkedés segíti.

\section{TÁBLÁZAT}

Az Oktatási Minisztérium tervezett intézkedései és alintézkedései a Humáneröforrás-fejlesztés valamint a Regionális Fejlesztési operatív programban

(Planned Measures and Submeasures of the Human Resource Development and the Regional Development Operative Programmes)

\begin{tabular}{|l|c|c|c|c|}
\hline \multirow{2}{*}{ Intézkedések és alintézkedéseik } & \multicolumn{3}{|c|}{ Strukturális Alapok forrásai } \\
\cline { 2 - 5 } & \multicolumn{2}{|c|}{ M euró } & \multicolumn{2}{c|}{ Mrd Ft } \\
\cline { 2 - 5 } & ESZA & ERFA & ESZA & ERFA \\
\hline Humánerőforrás-fejlesztés OP & 93,7 & 71 & $\sim 23,7$ & $\sim 18$ \\
\hline $\begin{array}{l}\text { 2.1. Hátrányos helyzetü, köztük roma fiatalok esélyegyen- } \\
\text { löségének biztosítása }\end{array}$ & 18,4 & - & $\sim 4,6$ & - \\
\hline $\begin{array}{l}\text { A) Hátrányos helyzetü, köztük roma gyermekek } \\
\text { integrált keretek között megvalósuló, minőségi okta- } \\
\text { tásának támogatása }\end{array}$ & & & & \\
\hline $\begin{array}{l}\text { B) Hátrányos helyzetú, köztük roma gyermekek } \\
\text { esélyegyenlöségét biztosító integrációs eljárások, } \\
\text { módszerek támogatása }\end{array}$ & & & & \\
\hline $\begin{array}{l}\text { C) Diszkrimináció-mentes oktatási gyakorlat támo- } \\
\text { gatása, az ehhez kapcsolódó képzések és jelzörend- } \\
\text { szer kialakítása }\end{array}$ & & & & \\
\hline D) Fogyatékkal élö fiatalok integrált oktatása & & & & \\
\hline
\end{tabular}




\begin{tabular}{|c|c|c|c|c|}
\hline \multirow{3}{*}{ Intézkedések és alintézkedéseik } & \multicolumn{4}{|c|}{ Strukturális Alapok forrásai } \\
\hline & \multicolumn{2}{|c|}{ M euró } & \multicolumn{2}{|c|}{ Mrd Ft } \\
\hline & ESZA & ERFA & ESZA & ERFA \\
\hline $\begin{array}{l}\text { 3.1. Az egész életen át tartó tanuláshoz szükséges készsé- } \\
\text { gek és képességek fejlesztése }\end{array}$ & 24,4 & - & $\sim 6,2$ & - \\
\hline A) Az alapkészségek fejlesztése & & & & \\
\hline B) A szociális és életviteli kompetenciák fejlesztése & & & & \\
\hline C) Az idegennyelvi képzés feltételrendszerének fejlesztése & & & & \\
\hline $\begin{array}{l}\text { D) Az informatikai készségek fejlesztése, informati- } \\
\text { kai tartalomfejlesztés }\end{array}$ & & & & \\
\hline $\begin{array}{l}\text { E) A környezettudatosság erösítése és a környezeti } \\
\text { nevelés fejlesztése }\end{array}$ & & & & \\
\hline $\begin{array}{l}\text { 3.2. A munkaeró-piaci integráció segitése a képzés tartal- } \\
\text { mának fejlesztésével }\end{array}$ & 30,5 & - & $\sim 7,7$ & - \\
\hline $\begin{array}{l}\text { A) A moduláris rendszerü képzés és tananyag fej- } \\
\text { lesztése, az elözetesen megszerzett tudás értékelése } \\
\text { és beszámítása }\end{array}$ & & & & \\
\hline $\begin{array}{l}\text { B) A szakképzó évfolyamokon zajló képzés tartalmi, } \\
\text { módszertani fejlesztése a mukaerö-piaci esélyek } \\
\text { növelése céljából }\end{array}$ & & & & \\
\hline $\begin{array}{l}\text { C) A lemorzsolódó fiatalok reintegrációja a szakis- } \\
\text { kolai képzésbe }\end{array}$ & & & & \\
\hline $\begin{array}{l}\text { D) A gazdasági környezethez alkalmazkodó, integ- } \\
\text { rált szakképzö intézmények fejlesztése }\end{array}$ & & & & \\
\hline 3.3. Az oktatási, képzési rendszer korszerüsitése & 20,4 & - & $\sim 5,2$ & - \\
\hline $\begin{array}{l}\text { A) Pályaorientációs, pályaválasztási és követỏ rend- } \\
\text { szerek fejlesztése }\end{array}$ & & & & \\
\hline $\begin{array}{l}\text { B) A komprehenzív iskola modelljének kidolgozása } \\
\text { és megvalósítása }\end{array}$ & & & & \\
\hline $\begin{array}{l}\text { C) Átfogó intézményfejlesztési és minöségfejlesztési } \\
\text { rendszerek kialakítása }\end{array}$ & & & & \\
\hline $\begin{array}{l}\text { D) Távoktatás fejlesztése az iskolai rendszerú kép- } \\
\text { zésben és a szakoktatásban, szakképzésben }\end{array}$ & & & & \\
\hline 5.1. Az oktatási infrastruktúra fejlesztése & - & 71 & $=$ & $\sim 15$ \\
\hline $\begin{array}{l}\text { A) Gyógypedagógiai és integrált oktatásban részesü- } \\
\text { lö fogyatékkal élö gyermekek, tanulók és fiatalok } \\
\text { esélyegyenlőségét segítő oktatási feltételek javítása }\end{array}$ & & & & \\
\hline $\begin{array}{l}\text { B) A korszerü peđagógiai elméletet és gyakorlatot } \\
\text { funkcionálisan kiszolgáló, egészséges és akadály- } \\
\text { mentes környezetet biztosító, gazdaságosan fenn- } \\
\text { tartható közoktatási épületállomány fejlesztése }\end{array}$ & & & & \\
\hline $\begin{array}{l}\text { C) A funkcionális kollégiumi modell feltételeinek } \\
\text { kialakítása }\end{array}$ & & & & \\
\hline $\begin{array}{l}\text { D) A fenntartható fejlödésnek megfelelö, a környe- } \\
\text { zettel harmóniában múködö társadalom értékeit, } \\
\text { mintáit közvetítö nevelési, oktatási színterek (erdei } \\
\text { iskolák, oktatási központok) bővítése, fejlesztése }\end{array}$ & & & & \\
\hline Regionális Operatív Program & 14,4 & 72 & $\sim 3,6$ & $\sim 18,2$ \\
\hline Regionális tudásközpontok kialakítása & 14,4 & - & $\sim 3,6$ & - \\
\hline Vidéki felsőoktatási intézmények infrastruktúrájának fejlesztése & - & 72 & - & $\sim 18,2$ \\
\hline
\end{tabular}

Forrás: Oktatási Minisztérium. 
Az NFT és a HEF OP tartalmazza a Oktatási Minisztérium tervezett intézkedésejnek és alintézkedéseinek tömör leírását. A továbbiakban azt kívánjuk bemutatni, hogy melyek voltak azok a szempontok, megfontolások, amelyekre az OM-nak az intézkedések (és alintézkedések) tervezésekor megkülönböztetett figyelmet kellett fordítani.

1) Összhang biztosítása az oktatási-képzési ágazat fejlesztési prioritásai, valamint a Nemzetj Fejlesztési Terv már rögzített átfogó célkitüzései között. A kapcsolódásokat a 2. táblázat szemlélteti.

\section{TÁBLÁZAT}

A Nemzeti Fejlesztési Terv specifikus céljai és a Humáneröforrás-fejlesztés Operatív Program prioritásai közötti kapcsolatok intenzitása

(The Intensity of Connection between the Specific Objectives of National Development Plan and the Priorities of the Human Resources Development Operative Programme)

\begin{tabular}{|c|c|c|c|}
\hline $\begin{array}{l}\text { HEF OP } \\
\text { prioritások }\end{array}$ & $\begin{array}{c}\text { A termelöszek- } \\
\text { tor verseny- } \\
\text { képességének } \\
\text { javitása }\end{array}$ & $\begin{array}{c}\text { Foglalkoztatás } \\
\text { bövítése és } \\
\text { humáneröfor- } \\
\text { rás-fejlesztés }\end{array}$ & $\begin{array}{c}\text { A környezeti } \\
\text { feltételek és az } \\
\text { egészségi álla- } \\
\text { pot javitása }\end{array}$ \\
\hline $\begin{array}{c}\text { Aktív munkaeró-piaci politikák } \\
\text { támogatása }\end{array}$ & $* *$ & $* * *$ & $*$ \\
\hline $\begin{array}{l}\text { Társadalmi kirekesztés elleni } \\
\text { küzdelem a munkaerőpiacra } \\
\text { történő belépés segítésével }\end{array}$ & $* *$ & $* * *$ & $*$ \\
\hline $\begin{array}{c}\text { Oktatás, képzés támogatása az } \\
\text { egész életen át tartó tanulás } \\
\text { politikájának részeként }\end{array}$ & $* * *$ & $* * *$ & $* *$ \\
\hline $\begin{array}{c}\text { Alkalmazkodóképesség és } \\
\text { vállalkozói készségek } \\
\text { fejlesztése }\end{array}$ & $* * *$ & $* * *$ & $*$ \\
\hline $\begin{array}{l}\text { Humánerőforrás-fejlesztéshez } \\
\text { kapcsolódó infrastruktúra- } \\
\text { fejlesztés }\end{array}$ & $* *$ & $* * *$ & $*$ \\
\hline
\end{tabular}

Megjegyzés: A célok és prioritások közötti kapcsolatok intenzitásának mértéke:

* gyenge

** közepes

$* * *$ erős

Forrás: Humánerőforrás-fejlesztés Operatív Program Melléklete. 
2) Összhang és szinergia megteremtése az oktatási-képzési ágazat intézkedései és a HEF egyéb - mindenekelött a foglalkoztatási és szociális terület - fejlesztési tervei között. (Külön meg kell említeni, hogy a felnöttképzés rendszerének a fejlesztésére vonatkozó intézkedés, noha a Fogłalkoztatáspolitikai és Munkaügyi Minisztérium (FMM) kompetenciája, szerves részét képezi az egész életen át tartó tanulásnak.) A 3. táblázat ezeket a kapcsolódásokat szemlélteti.

3) Az Európai Foglalkoztatási Stratégiában és a 2002. évi Foglalkoztatáspolitikai Irányvonalakban megfogalmazott célok, továbbá az Európai Szociális Alapról szóló rendelet elörrásainak és elveinek messzemenö figyelembevétele. Az összefüggéseket a 4. táblázat ábrázolja.

4) Az intézkedések segítsék eló az elmúlt évek hazai folyamatainak elemzése során az oktatás, szakképzés területein azonosított szük keresztmetszetek, feszültségpontok felszámolását, egyidejủleg szolgálják a Kormányprogramban megfogalmazott rövid és középtávú konkrét fejlesztési célok megvalósítását. Az oktatásszakképzés területein tervezett intézkedések (a hátrányos helyzetü, köztük roma fiatalok esélyegyenlóségének biztosítása, az egész életen át tartótanuláshoz szükséges készségek és képességek fejlesztése, a munkaerö-piaci integráció a képzés tartalmának fejlesztésével, az oktatási-képzési rendszer korszerüsítése, az oktatási infrastruktúra fejlesztése) és alintézkedések egyértelműen az NFT stratégia, ill. a HEF OP helyzetelemzésben feltárt fogyatékosságok, gyengeségek kiküszöbölésének, az oktatási-képzési rendszer fejlesztésének követelményeit juttatják érvényre.

5) Az oktatási, képzési intézkedések és alintézkedések tegyenek eleget az Európai Szociális Alapról, ill. az Európai Regionális Fejlesztési Alapról szóló rendeletekben, egyéb idevágó közösségi jogszabályokban rögzített formai követelményeknek, azaz a tervezett intézkedések és alintézkedések, jogosultak" legyenek az alapok pénzügyi forrásainak az igénybevételére.

6) Garancia arra vonatkozóan, hogy a tervezett intézkedések, alintézkedések társfinanszírozásához szükséges hazai források rendelkezésre állnak.

7) Összhang kialakítása a regionális szintü (NUTS 2) tervezéssel és fejlesztéssel. A közösségi támogatások egy jelentős része, mindenekelőtt az Európai Regionális Fejlesztési Alap (ERFA) a területfejlesztési célok finanszírozását szolgálja. Ez érvényes a humán eröforrások fejlesztését céłzó fizikai természetủ tevékenységekre is. Az ilyen céłokat szolgáló fejlesztéseket, infrastrukturális természetú oeruházásokat (új építmények létesítése, nagy értékủ berendezések, felszerelés beszerzése stb.) kizárólag az ERFA forrásaiból lehet finanszirozni. Megkülönböztetett fontossága volt tehát annak, hogy a regionális fejlesztési tervekben is helyet kapjanak a ténylegesen a területi kiegyenlítést, a régiók humánerőforrás-fejlesztési céljait szolgáló oktatási, képzési intézkedések. 
Forgács András :

Az Európai Szociális Alap és az Európai Unió oktatáspolitikája

Tér és Társadalom 17. évf. 2003/1. 131-153. p.

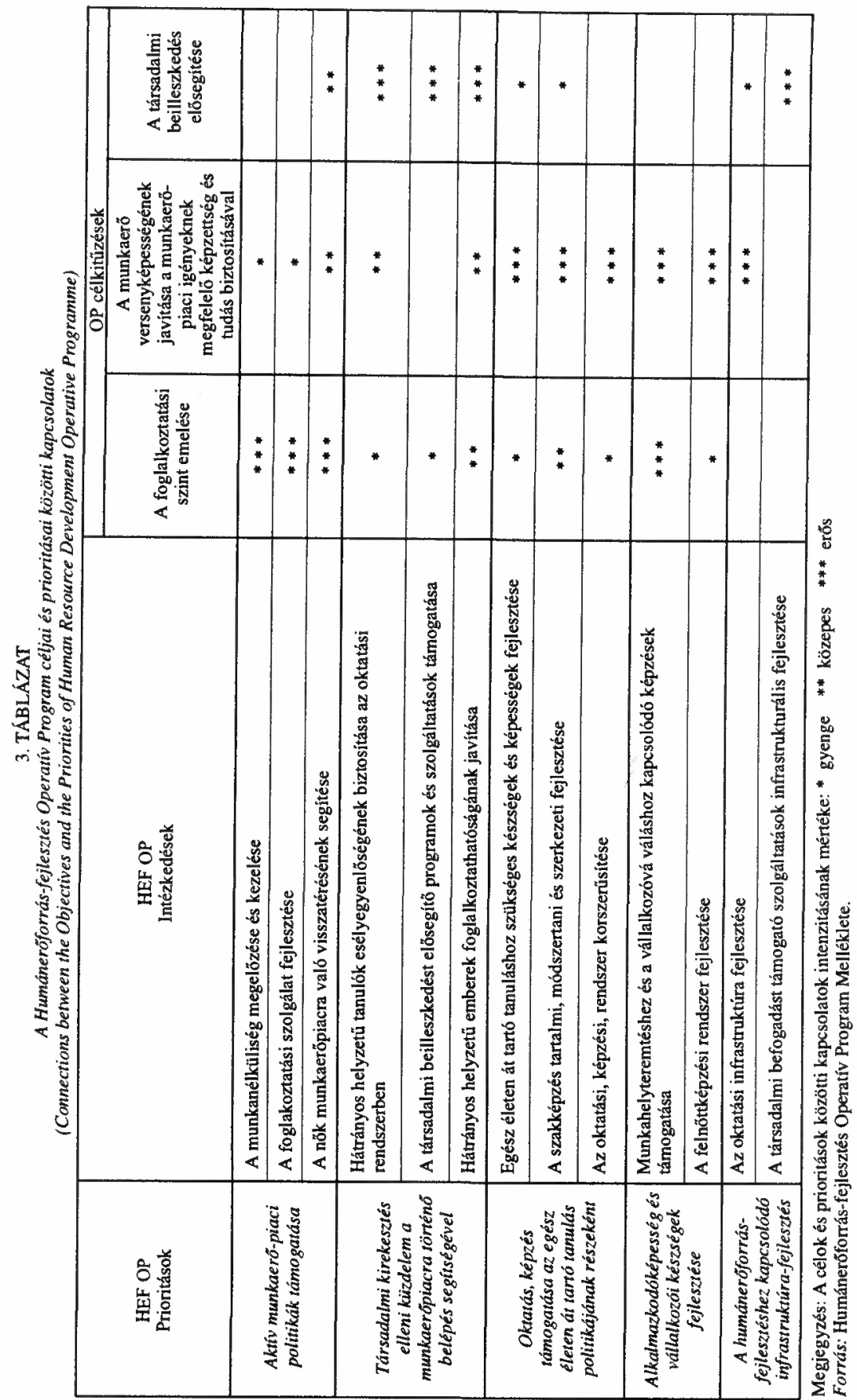


Tér és Társadalom 17. évf. 2003/1. 131-153. p.

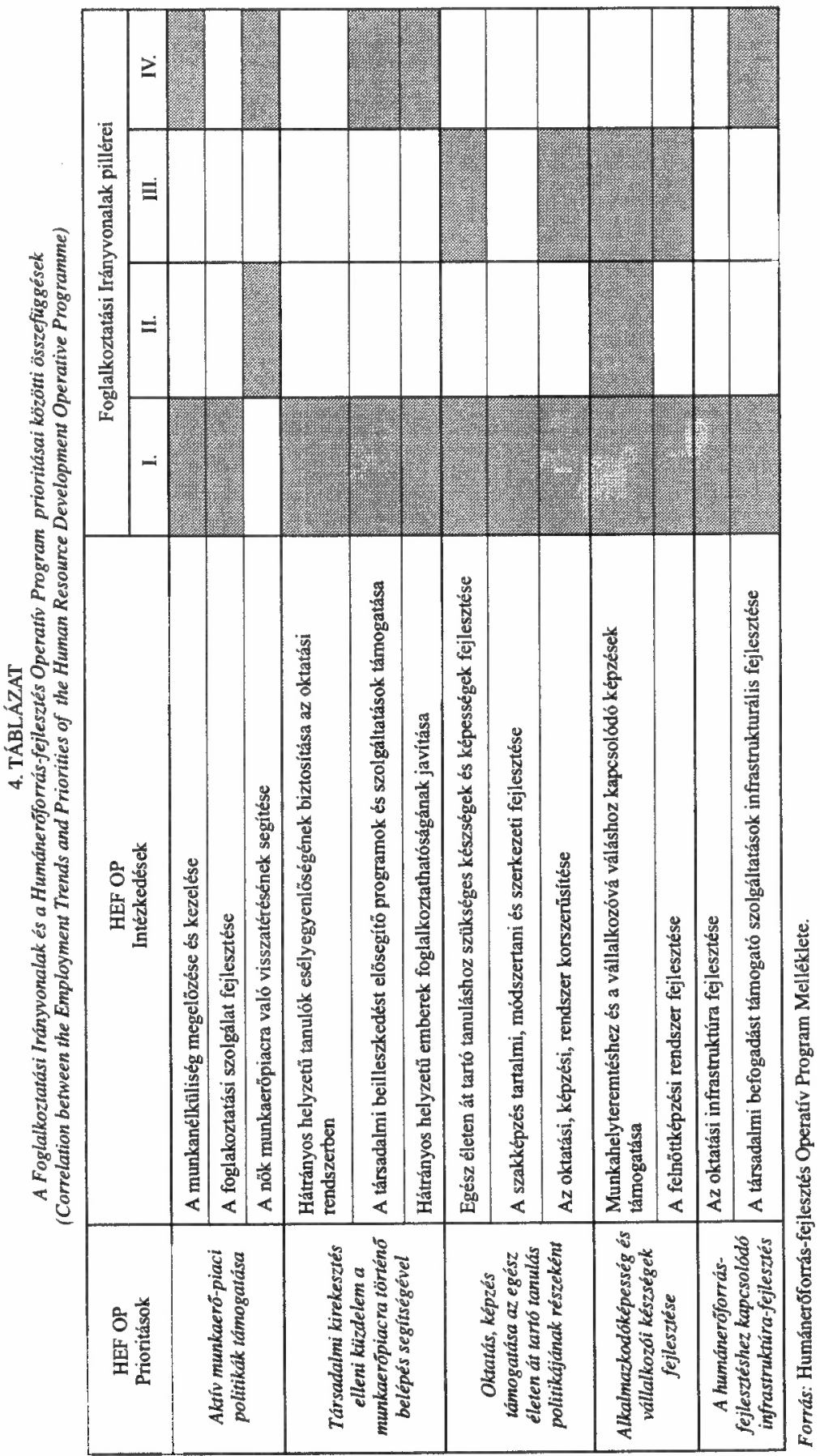


Összefoglalva megállapítható, hogy az oktatás és képzés fejlesztésének irányát és konkrét célrendszerét a továbbiakban az uniós támogatáspolitika feltételrendszere mentén, a közösségi pénzügyi támogatás kínálta lehetőségek kihasználásával, a magyar adottságokból, a valós szükségletekből és fejlesztési igényekből kiindulva, s végül, de nem utoljára az európai foglalkoztatáspolitikai stratégiába illesztett oktatáspolitikai prioritásokra kell építeni. E komplex feltételrendszer érvényesítése természetesen nemcsak az oktatási-szakképzési ágazati tervezỏmunkával, hanem az Operatív Programban érintett, a többi ágazatot irányító tárcákkal való együttmủködés elveivel és gyakorlatával szemben is újszerü követelményeket támasztott, ill. támaszt folyamatosan. A tervezỏmunka gyakorlatilag a rivalizálás és az együttmüködés sajătos szintézisén alapuló, meglehetősen bonyolult iteratív alkufolyamatnak tekinthető, amelyben a résztvevőknek folyamatosan össze kell tudniuk egyeztetni a közösségi forrásokért folytatott versengést a humán erőforrások fejlesztése kapcsán a fejlesztési prioritások, intézkedések és tevékenységek koherens és konzisztens megfogalmazásával. Ez egyebek mellett messzemenö türelmet, kompromisszumkészséget és megértést követel az érintettektől.

Az NFT tervezése során már eddig is felszinre került néhány olyan hiányosság, ami minden tekintetben ténylegesen gátja a koherens oktatási, képzési fejlesztési intézkedések kidolgozásának. Elsősorban az európai oktatáspolitika szellemiségének megfelelö átfogó és komplex középtávú oktatásfejlesztési stratégia, s ezen belül az egész életen tartó tanulás stratégiájának hiånyát kell említeni. Ezen a helyzeten mielőbb változtatni kell.

Az NFT intézkedéseinek pályázatok kiírására alkalmas operacionalizált tevékenységekre történő lebontása a tervező munka komoly kihívást jelentö utolsó fázisa lesz. Ezt a munkát a következő hetekben feltétlenül el kell végezni ahhoz, hogy 2004 elejétỏl a Strukturális Alapok forrásai megnyíljanak Magyarország számára. Magától értetődik, hogy az NFT oktatási, képzési intézkedései véglegesítésének, az intézkedések eredményes végrehajtásának megkerülhetetlen elöfeltétele marad egy hatékony és átlátható végrehajtási intézményrendszer kialakításához szükséges szervezeti, személyi és technikai feltételrendszer megteremtése. Képzések, széles körú tájékoztató munka révén a pályázati munkában érdekelt valamennyi szereplő számára hozzáférhetővé kell tenni az oktatás, képzés terén megszerezhető forrásokról szóló, továbbá a sikeres pályázatok készítéséhez elengedhetetlen ismereteket. Mindez nem csupán az oktatási kormányzattól, hanem az NFT kidolgozásának és végrehajtásának irányításában, koordinálásában érintett központi kormányzati szervektől, önkormányzati szervektől, tudományos mühelyektöl, szakmai szervezetektöl, szociális partnerektöl is további kitartó és összehangolt erőfeszítéseket igényel.

\section{Jegyzetek}

1 Természetesen a Strukturális Alapok, így az Európai Szociális Alap korábban is támogathatta és támogatta is az oktatás és a képzés fejlesztését, ám mindezidáig ez nem szerepelt egyetlen közösségi dokumentumban sem önálló fejlesztési prioritásként. Gyakran a kedvezményezett tagállam (pl. Íror- 
szág, Portugália) saját elhatározás alapján szentelte a közösségi támogatások igen számottevő hányadát az oktatási és képzési rendszerek fejlesztésére.

Külön tanulmány tárgyát kell majd képeznie annak, hogy milyen lehetöségeket kínálnak az Európai Regionális Fejlesztési Alap forrásai az oktatás, képzés fejlesztésére. Itt csupán annak jelzésére szorítkozhatunk hogy a támogatások jellege tekintetében rámutassunk a két strukturális alap közötti legalapvetőbb kuilönbségre: míg az ESZA kizárólag emberekbe, személyekbe és oktatási képzési rendszerekbe történó nem fizikai jellegú beruházásokat (ún. rendszerfejlesztést) támogat, addig az ERFA forrásai az oktatás, képzés bövítését, fejlesztését és modernizálását szolgáló infrastrukturális jellegü fejlesztésekre (új oktatási épületek, képzöintézmények létesítése, ill. meglévök korszerủsítése, új berendezések, felszerelések beszerzése és beállítása) vehetók igénybe. Ily módon a két alap forrásai gyakorlatilag egymást kiegészítik, és igénybevételuikre is a komplementaritás messzemenỏ figyelembevételével kerülhet sor.

${ }^{3}$ Az oktatás egészen a Maastrichti Szerzödés megszületéséig (1992) nem is képezte a közösségi jog részét.

${ }^{4}$ A berlini csúcson átfogó és részletes határozatokat hoztak az új programozási időszakban (2000-2006) érvényesülö strukturális politika tartalmáról, kereteiröl, prioritásairól, továbbá a megvalósításához rendelkezésre álló közösségi források nagyságrendjéröl és elosztásának elveiröl. Az ott hozott határozatok alapján megfelelő tanácsi, bizottsági rendeletek szullettek.

${ }^{5}$ A Tanács $1784 / 99 / \mathrm{EK}$ sz. rendelete.

${ }^{6}$ A különböző Strukturális Alapok és a Kohéziós Alap felhasználása közötti összhang megteremtésének kỏvetelményével és módozataival foglalkozó, később született terjedelmes bizottsági dokumentum (Commission Communication No 1999/C 267/02 concerning the Structural Funds and their coordination with the Cohesion Fund) ezt a tézist tételesen is megfogalmazza. Leszögezi, hogy az alapoktatásban és -képzésben elsajátítható készségek és képességek fejlesztése az alapok forrásaiból csak abban az esetben támogatható, ha ,a tevékenység világosan kapcsolódik a munkaerőpiac múködésének és/vagy az egyének foglal koztatásának javításához".

7 1784/99/EK sz. rendelet 2. cikk a., b., d., e. pontjai.

8 A Tanács 2001. július 13-i ,301G0720(01) sz. Állásfoglalása az oktatás és szakképzés szerepéröl a foglalkoztatáspolitika területén (OJ C204, 20/07/2001 0001-0002 old.).

${ }^{9}$ A Tanács 2001. jan. 19-i 2001/163/EC sz. határozata.

${ }^{10}$ Az Európai Bizottság felfogása szerint az egész életen át tartó tanulás az egyén életén átíveló „megszakítás nélküli folyamatos tevékenység”, amelynek „nélkülözhetetlen fundamentuma a korai gyerekkortól kezdödően a mindenki számára biztosított jó minőségü alapoktatás ... majaj azt kơvetően az alapozó szakképzés..." Az egész életen át tartó tanulás magában foglalja mind a formális (oktatási és szakképzési alapintézményekben megvalósuló és rendszerint elismert bizonyítvánnyal, szakképesítéssel záruló), mind a nem-formális ( a formális rendszerek keretein kívủil pl. magántanfolyamokon, vagy munkahelyen történö), mind az informális (a mindennapi élet során végzett nem tưdatos tanulási tevékenység) tanulást (Memorandum... 2000).

${ }^{11}$ Council Decision of 18 February 2002 on Guidelines for Member States' employment policies for the year 2002 (2002/177/EC).

${ }^{12}$ Az Irányvonalak Horizontális célok c. fejezetének B. pontja.

${ }^{13}$ A Tanács 2002. febr. 18-i 2002/178/EC sz. ajånlása. A dokumentum egyebek között nyomatékosan felhivja Görögország, Spanyolország, Olaszország, Ausztria és Portugália figyel mét az egész életen át történỏ tanulás átfogó és koherens stratégiájának kidolgozására. Portugália esetében, figyelemmel a lakosság alacsony képzettségi szintjére, külơn is sürgeti az oktatási-képzési rendszerek fejlesztését.

${ }^{14}$ Magyarország társult országként jelenleg is részt vesz az ún. nyitott koordináció folyamatában, egyebek mellett részese az egész életen át tartó tanulással kapcsolatos közösségi eszmecseréknek, szerepet vállal az oktatás minóségi indikátorainak kidolgozását szolgáló, valamint az európai oktatási és képzési rendszerek jövendö céljainak megvalósítására elfogadott munkaprogram végrehajtását koordinálni hivatott szakértöi munkálatokban (1. ezzel kapcsolatban: Report from the Education... 2001; Detailed Work Programme... 2002).

15 Ilyen területnek lehet tekinteni a hátrányos helyzetü térségek és különbözö társadalmi csoportok felzárkóztatásához elengedhetetlen oktatási, képzési programok, infrastrukturális fejlesztések tetemes költségvonzatát.

${ }^{16}$ Az Európai Bizottság éppen a Strukturális Alapok forrásainak hatékony, teljes körü és „EU-konform” felhasználása szempontjából kiemelt fontosságot tulajdonít annak, hogy a csatlakozás idöpontjára 
Magyarország minden tekintetben felkészüljön az EU strukturális támogatásainak az igénybevételére. A PHARE program keretében az FVM és a MEH koordinációja mellett az érintett tárcák bevonásával két átfogó, ún. speciális felkészítési program végrehajtása van folyamatban. Mindkẻt programnak az a feladata, hogy a tagállamok közremüködésével ês segítségével szervezetten támogassa az érintett kormányzati szervezetek, önkormányzatok, illetve a régiók fejlesztési ìgynökségeinek egyebek mellett az Európai Szociális Alap kezelésére történỏ felkészullését a szükséges szervezeti és jogi keretek, humán kapacitások megteremtésében. E programok keretében széles körü intézményfejlesztési, jogszabály alkotási tevékenységgel egyidejüleg - intenzív szakmai-technikai tanácsadásra, szervezett képzésekre, a tagállamok élenjáró tapasztalatainak a megismerésére szolgáló tanulmányutakra építve - folyik az Alapok kezeléséhez szủikséges sokoldalú szakmai ismeretek átadása.

17 A FIDESZ-kormány 1998. évi programja, pl. leszögezte, hogy a „Kormány az oktatási tárca által kidolgozott humáneröforrás-fejlesztési stratégia” révén kívánja a „változó gazdasági, munkaerö-piaci körülményekhez alkotó módon alkalmazkodni képes munkaeró képzését és fejlesztését megoldani”. A 2002. évi Kormányprogram pedig - az EU oktatáspolitikai céljaival teljes összhangban - megkülönböztetett fontosságot tulajdonít az oktatásnak és képzésnek a területi kủlönbségek csökkentésében, a hátrányos társadalmi helyzetủ fiatalok felzárkóztatásában, az oktatás-képzés és a munkaerö-piaci igények közötti fokozottabb összhang megteremtésében egyebek mellett a készségek és képességek fejlesztése, a korszerü tartalmak oktatásának erōsítése, az iskolák rekonstrukciója stb. révén.

18 A Nemzeti Fejlesztési Terv és az öt operativ program, köztük a HEF OP teljes terjedelemben olvasható és letölthetó a http/www. Euforium.hu honlapon, ill. honlapról.

19 A Kormány 2002 decemberének legvégén fogadta el az NFT jelenlegi elsỏ változatát. A végsö belső egyeztetések és finomítások után 2003 márciusában kerül sor az NFT hivatalos átadására Briusszelben. Ezt a magyar kormány és az Európai Bizottság közơtti tỏbb fordulós tárgyalások követik majd, amelyek során eldöl, hogy melyek lesznek azok a fejlesztési elgondolások az NFT-ben, amelyek megvalósításához Magyarország ténylegesen kỏzösségi támogatásra számíthat. Az NFT tehát még lényegesen módosulhat mind a tervezett intézkedések, mind pedig a támogatások nagyságrendje és operatív programok, intézkedések szerinti elosztása tekintetében.

${ }^{20}$ L. ezzel összefüggésben Az Európai Szociális Alap feladatai az oktatás, képzés terén a 2000-2006-os programozási idöszakban c. fejezetben az 1784/99/EK rendelet ismertetését.

\section{Irodalom}

Council Decision of 18 February 2002 on Guidelines for Member States' employment policies for the year 2002. (2002) Brüsszel, (2002/177/EC).

Communication from the Commission to the Council, Draft Joint Employment Report. (2002) $\operatorname{COM}(2002) 621$ final. Brüsszel.

Communication from the Commission to the Council, the European Parlament and the Economic and Social Committee on European Social Fund Support for the European Employment Strategy. (2001) COM(2001)16 final, 2001/0208(CNS), Brùsszel, 2001.01.16.

Detailed Work Programme for the Follow-up of the Objectives of Education and Training Systems in Europe (Decision of the Council Education). (2002) Brisszel, 2002.02.14.

European Report on Education and Training in Employment Policies. (2001a) Volume 1. - Analysis of the 2000 National Action Plans for Employment. Commission Working Paper, Brüsszel, április (szám nélkül).

European Report on Education and Training in Employment Policies. (2001b) Volume 2. - Analysis by Member State of the National Action Plan for Employment, for 2000. Commission working document. Brüsszel, április (szám nélkül).

Memorandum az egész életen át tartó tanulásról. (2000) SEC(2000)1832, Brủisszel, 2000,10.30.

Report from the Education Council to the European Council "The concrete Future Objectives of Education and Training Systems" (Council of the European Union). (2001) 5980/01 EDUC 23, Brissszel, 2001.02.14. 